Валерій ФІАЛКО

\title{
ОБРАЗНА МОВА СЦЕНІЧНОГО МИСТЕЦТВА В ОСМИСЛЕННІ ТЕОРЕТИКІВ І ПРАКТИКІВ ТЕАТРУ
}

У статті розглянуто коло питань, пов'язаних із образною мовою театру, сформульованих у праиях режисерів і театрознавців. Основна увага сфокусована на теоретичному доробку видатних реформаторів сиени Вс. Мейєрхольда, Леся Курбаса та їх учнів. Окреслюючи наукові пріоритети діячів сиени другої половини ХХ століття, автор виокремлює роботи Г. Товстоногова, Д. Лідера, М. Рехельса, М. Френкеля та ін.

Ключові слова: мова театру, сценічна лексика, Вс. Мейєрхольд, Лесь Курбас.

В статье рассмотрен круг вопросов, связанных с образным языком театра, сформулированных в работах режиссеров и театроведов. Основное внимание сфокусировано на теоретическом наследии вылдюшихся реформаторов сиены Вс. Мейерхольда, Леся Курбаса и их учеников. Очерчивая научные приоритеты деятелей сиены второй половины ХХ столетия, автор выделяет работы Г. Товстоногова, Д. Лидера, М. Рехельса, М. Френкеля и др.

Ключевые слова: язык театра, сценическая лексика, Вс. Мейерхольд, Лесь Курбас.

The article considers a number of issues related to the figurative language of the theater, formulated in the writings of the directors and theater critics. The main focus is on the theoretical studies of the prominent reformers of the stage, such as Vs. Meyerhold, Les Kurbas and their students. Outlining the scientific priorities of the figures of the second half of the twentieth century, the author singles out the works of G. Tovstonogov, D. Leader, M. Rekhels, M. Frenkel and others.

Key words: theater language, stage vocabulary, Vs. Meyerhold, Les Kurbas.

Питання образної мови театру впродовж багатьох десятиліть не втрачають своєї актуальності. Пильна увага до цього кола проблем, що іï проявляють як митці-практики, так і теоретики театру, зумовлена постійним оновленням сценічної лексики, динамікою трансформацій художніх структур, появою нових театральних систем та ін. В процесі осмислення набутого творчого досвіду відбувалося теоретичне осмислення методологічних засад і технологічних прийомів режисури, виокремлення принципів створення образної системи вистави, узгодження театральної термінології та ін., що знайшло своє висвітлення в теоретичних працях практиків і теоретиків театру.

Мета цієї статті - проаналізувати коло питань, безпосередньо пов'язаних із образною мовою театру, сформульованих у працях режисерів і театрознавців.

Особливе місце в цьому ряду посідають праці видатних реформаторів театру XX століття. У статтях, доповідях, лекціях та інших матеріалах, що становлять теоретичну спадщину Вс. Мейєрхольда, мова театру, сценічна лексика посідають чільне місце в контексті фундаментальної розробки концепції умовного театру. «Я брав і вивчав прийоми як такі, у плані технічному, і тому я міг би вже сьогодні, на основі цього вивчення, написати книгу, але яку книгу? - наприклад, “Технологія акторської гри”, або “Технологія режисури”, або “Технологія драматургії”. < ..> Коли я кажу про технологію, я також кажу про необхідність створення, приміром, театрального енциклопедичного словника, адже нам треба домовитися про иілу низку термінів» $[1,229 ; 230]$. Книжка, про яку йшлося у виступі Вс. Мейєрхольда на дискусії «Творча методологія театру імені Мейєрхольда», так і не була написана майстром. Однак уже в редагованому Вс. Мейєрхольдом журналі «Любов до трьох апельсинів» виразно простежується збільшення питомої ваги наукових публі- 
кацій. Як зазначає О. Клековкін, «суть повороту, здійсненого журналом, - у зміні орієнтації і переході від академічних проблем до проблем практичних, у пошуку відповіді на питання, що його згодом висунуть формалісти: як ие зроблено?» [2, 40]. Дослідження діапазону виражальних засобів, прийомів, якими оперує режисер, створюючи виставу, - наскрізна лінія теоретичної спадщини Вс. Мейєрхольда.

На Курсах майстерності сценічних постановок, згадував О. Грипич (секретар цих курсів): «Мейєрхольд учив, що у театрі не слід імітувати життя, намагаючись повторити його зовнішню форму, адже театр має свої театральні способи вираження. Все, що існує у театрі, підкоряється загальним театральним законам. Театр не конгломерат літератури, живопису, музики. Театр - мистецтво дії, що має власний самостійний зміст, специфічну, одному театрові притаманну форму». [3, 143].

Ключовим у системі теоретичних поглядів Вc. Мейєрхольда $є$ таке визначення: «Режисерський театр - це акторський театр плюс мистецтво композиції цілого» $[4,313]$. Біомеханіка, система акторських амплуа, образ-маска; гра, як першооснова сценічного мистецтва (гра актора 3 предметним світом вистави, зі своїми костюмами, гра 3 конструкцією); прийоми передгри, які «так готують глядача до сприйняття сценічного положення, що глядач усі подробиці отримує зі сцени в такому опрацьованому вигляді, що не мусить для засвоєння змісту, вкладеного в сцену, витрачати жодних зусиль» та ін. [1, 93], кардинально змінювали уявлення про принципи і методи творення образу акторами.

Мистецтво композиції цілого базувалося на принципово відмінних від запроваджуваного Аристотелем послідовного викладу подій у побудові твору. Формування позатекстової сценічної реальності, що її впроваджував у своїй практиці Вс. Мейєрхольд, передбачало монтажний принцип побудови образної системи вистави. Всі виражальні засоби театру: музична, пластично-просторова, світлова, темпоритмічна, часова партитури, прийоми балагану, цирку, пантоміми та ін., підпорядковуючись принципу монтажу, збагачували спектакль «новими образотворчими засобами, організм його розростався й ускладнювався, набуваючи форми складної театральної симфоHï̈» $[5,22]$.

Питання образної мови театру закономірно посідає центральне місце у системі поглядів Леся Курбаса на сценічну культуру, органічно випливає 3 його місії реформатора вітчизняного театраль- ного мистецтва. Всю теоретичну спадщину, яка відбиває погляди Леся Курбаса на проблему образної мови театру, можна умовно поділити на окремі рубрики.

До першої належить корпус статей митця, надрукованих у різнотипних виданнях упродовж 1910-х- 1930-х років, що позначилося на змісті й характері викладу, хоча й не завадило авторові постійно апелювати до зазначеної проблематики [6]. Врешті у МОБі він засновує журнал «Барикади театру» (1923-1925 pр.), аби зробити більш ефективним оприлюднення власного естетичного кредо.

Втім, основний масив документальних свідчень про погляди видатного митця на природу сценічного мистецтва, його генезу, мотивацію змін у способах образного висловлювання - цей масив утворюють численні протоколи окремих підрозділів колективів, створених і керованих ним самим. Йдеться, приміром, про діяльність Режисерської лабораторії чи Режисерського штабу, Термінологічної комісії чи Станції фіксації та систематизації досвіду тощо. До цієї ж категорії матеріалів належать чернетки статей, теоретичних розвідок, які залишилися незавершеними.

Нарешті, принципово важливими свідченнями інтелектуальної праці Леся Курбаса, його ідей і рефлексій у відповідній сфері $є$ щоденникові записи [7].

Якщо спробувати коротко окреслити коло найважливіших для Леся Курбаса тем, що увиразнюють саму категорію образної мови як такої, то слід зауважити: всі вони (ці теми) поставали в його творчій свідомості ще $з$ середини 1910-х років, у час започаткування й розбудови ним режисерського театру. Для його позначення митець вживав вираз «театр єдиної волі», тим самим концептуально окреслюючи нові естетичні підходи. В цьому сенсі на особливу увагу заслуговує акцентація ролі просторових чинників у створенні образу вистави, переосмислення фактора часу як джерела «видобування» потужної образної енергіï. На ці процеси нашаровуються спроби Леся Курбаса прищепити національному театрові інтерес до експресіоністської культури, запровадити конструктивістську модель побудови сценічного середовища. Тим самим він утворює радикально інакшу творчу ситуацію сценічного існування актора. В межах посталої у тих процесах нової «художньої реальності» Лесь Курбас переосмислює традиційні засади національного сценічного мистецтва, особливо прискіпливо розглядає категорії сценічного часу, ритму, темпу, пауз, енергій, акцентованої дії тощо. 
Всі ці процеси сукупно утворили плідний грунт для формування та впровадження методу «образних перетворень», по суті своєрідного засобу образного мовлення, яке щонайкраще естетично характеризує Театр Леся Курбаса. У його межах склалася оригінальна мистецька школа, відома як «березільська», чиї представники, передусім режисери (В. Василько, М. Верхацький, С. Бондарчук) вирізнялися загостреною увагою до теоретичних аспектів театральної практики [8; $9 ; 10]$. Їхні статті й книжки демонстрували прагнення митців школи Леся Курбаса до створення теорії театру, режисури. Це можна стверджувати й стосовно вже їхніх власних учнів. Показовим у цьому сенсі є приклад В. Довбищенка, якому В. Василько прищепив інтерес до проблем теорії театру, систем його образного мовлення [11].

Дослідження природи образної мови театру посідає центральне місце в монографіях і статтях практиків радянського театру другої половини $\mathrm{XX}$ століття. В естетичних вимірах психологічного театру проблеми створення художньої цілісності вистави розглядалися А. Поповим [12]. У працях Г. Товстоногова системно аналізується широке коло питань щодо формування образної системи вистави, всебічно осмислюється запроваджений К. Станіславським термін «природа почуттів», який «стосується не лише існування актора на сцені, а й поєднання цього існування зі світом твору, з авторським баченням життя, з тією точкою зору, з якої творець п'єси, основи вистави, дивиться на події, на дійсність, на людей. <..> Природа почуттів - це не компонент спектаклю, а те єдине, що обумовлює всі його компоненти, осереддям своїм обираючи актора, який грає дану роль у даній п'єсі у постановці даного режисера» $[13,51 ; 52]$.

Технологію режисури досліджував у своїх працях Л. Варпаховський. Спираючись на досвід співпраці з Мейєрхольдом, він творчо переосмислює методологічні засади створення образної партитури сценічного твору, діагональної композиції вистави, принципів побудови сценічної дії за законами музичної композиції, розробку методів фіксації вистави. Леонід Варпаховський зазначав: «... доти, доки ми не навчимося переносити виставу на папір, ми не зможемо досліджувати будь-який його елемент у статиці, ми не зможемо цитувати його. Коли ми навчимося записувати спектакль, наука про театр перестане бути примарно невловимою» $[14,160]$.

У переважній більшості теоретичних праць практиків сцени питання образної мови виокрем- лювались у контексті аналізу співтворчості авторського колективу вистави, режисерської інтерпретації драматургічного матеріалу, жанрово-стильового вирішення вистав, образної побудови сиенічної діï, що засвідчують роботи М. Акімова, А. Васильєва, А. Гончарова, С. Данченка, М. Захарова, О. Реміза, М. Рехельса, М. Резніковича В. Харченка, Л. Танюка та ін.

Данило Лідер у статтях і бесідах (зафіксованих мистецтвознавцями) всебічно розглядає створені ним образно-пластичні структури вистав. Разом 3 тим Д. Лідер визначає притаманні йому методологічні засади творення зорового образу вистави, котрі обіймають вивчення комплексу питань, пов'язаних із п'єсою, особливостями поетики автора, з формулюванням особистих позицій щодо проблем, які містяться в тексті, а також щодо проблем дійсності, відбитих у драматургії; крім того, митець окреслює свої позиції щодо визначення певних питань, зокрема, за якими законами узагальнювати матеріал п’єси, які іiі події будувати відповідно до лінії образності, через які матеріальні предмети виразити метафору тощо $[15 ; 16]$. Спираючись на ці методологічні засади, учні Д. Лідера суттєво вплинуть на оновлення образної мови українського театру 1980-1990-х років.

Узагальнюючи принципи функціонування дієвої сценографії в практиці художників радянського театру 1960 - першої половини 1980-х років, сценічна лексика розглядалась у монографіях М. Френкеля «Пластика сценического пространства: Некоторые вопросы теории и практики сценографии» [17], «Современная сценография» [18].

Творчі пошуки Е. Барби, П. Брука, Є. Гротовського, що знайшли своє осмислення в презентованих ними теоретичних працях, висвітлюють процеси кардинального оновлення образної мови європейського театру другої половини $\mathrm{XX}$ - початку XX1 століття [19; 20; 21].

$\mathrm{y}$ театрознавчих дослідженнях мова театру, iii образна лексика постала предметом наукового вивчення в працях ленінградської театрознавчої школи, очолюваної А. Гвоздєвим [22]. Грунтуючись на методологічних засадах М. Германа, представники цієї школи у дослідженні театру спиралися насамперед на виставу. Історія драми поступилася місцем історії сценічного мистецтва. Предметом театрознавчих досліджень були позалітературні елементи театру, що кардинально змінило методологічні принципи аналізу його образної мови. 
Розвиток, взаємовплив і взаємозбагачення різноманітних художньо-естетичних напрямів $\mathrm{i}$ течій в театрі кінця XIX - першої третини XX століття простежується в працях Б. Алперса [23] і П. Маркова [24]. Водночас ці дослідження виходять далеко за межі фіксації мистецьких процесів означеного періоду. По суті, вони виявили певні закономірності оновлення образної лексики сценічного мистецтва XX століття.

Художньо-естетичні трансформації другої половини XX століття і, відповідно, різні аспекти розвитку театральної мови, досліджено у працях В. Берьозкіна, Н. Корнієнко, Р. Кречетової, В. Максимової, О. Мальцевої, К. Рудницького, А. Смелянського, Т. Шах-Азізової тощо. Істотні зміни в естетиці сучасного європейського театру висвітлено в теоретичних працях К. Бальме та Г.Т. Леманна $[25 ; 26]$.

В аспекті зазначеної у статті проблеми на увагу заслуговує монографія А. Михайлової «Образ спектаклю» [27]. Аналізуючи художній образ як динамічну цілісність, А. Михайлова розглядає основні стадії його буття: образ-замисел, художній твір, образ-сприймання, образ твору (або образ-підсумок). Поряд із цим підходом, зауважує А. Михайлова, «в теорії мистецтва загальноприйнятим є вивчення художнього образу як синхронної (“горизонтальної”) системи - комплексу пов'язаних рівновеликих образів, які розглядаються в рамках даного твору мистецтва як такі, що існують немовби одночасно (що не виключає, звісно, розгляд кожного з них у розвитку, обмеженому, проте, межами його буття в структурі твору» $[27,8]$. Думку про існування у структурі твору різномасштабних образів А. Михайлова підтверджує судженнями Б. Асаф'єва, В. Виноградова, В. Пудовкіна, С. Ейзенштейна, М. Гея: «Можна вважати твір єдиним великим образом, межі якого визначені чітко й всередині якого відбувається рух окремих образів, чиїм порогом безкінечного розвитку $\epsilon$ твір» $[28,91]$. Адаптація «горизонтального» підходу розгляду художнього образу до функціонування образної системи спектаклю передбачає виокремлення змістового аспекту «малого» образу (термін А. Михайлової) сценічного твору. Спираючись на теоретичні праці практиків театру, які розглядали партитуру вистави як «ланцюг безперервних конфліктів, поєдинків, які доходять, так би мовити, до “психологічного боксу”, створює партитуру спектаклю» [29, 242], «ланцюг дій у безперервному розвитку» $[30,166]$, «ланцюг мізансцен» [30, 105], можна стверджувати, що, йдучи за логікою режисерського мислення, саме мізансцени є тими малими образами, з яких формується образна система вистави. Грунтуючись на практиці театру 1960-1980-х років, М. Рехельс висновує: «Мізансцена - пластичний та звуковий образ, у центрі якого перебуває жива, діюча людина. Колір, світло, шуми та музика - додаткові, а слово і рух - основні її компоненти. Літературний образ під час переводу його в образ сценічний набуває форми мізансцени... Мізансцена, якщо вона точна - образ» [30, 105].

Оперування такими естетичними вимірами простежується ще в режисурі Л. Курбаса. Адже курбасівське «перетворення», за Н. Корнієнко, не слід розуміти «... утилітарно й шукати в ньому тільки метафору, символ, ейзенштейнівській “атракціон” тощо. Бо естетичне перетворення не тільки разовий знак певної реальності, як це поясняв Курбас попервах, натомість процес, тобто дія, акція, перевтілення ситуації. Таким чином, “перетворення" $\epsilon$ двоїстим. У вузькому сенсі це близьке метафорі та символу іносказання, чиє завдання - викликати одиничну, разову асоціацію. Проте Курбас розширив це поняття до вистави, синтетичної за своєю природою. Всі сценічні компоненти включаються у цілісний світ режисерського замислу. Акторські "перетворення" поєднуються 3 "візуальним" світом спектаклю, і тоді цілісним перетворенням стає мізансцена...» [31].

У другій половині 1980-го - 1990-х роках були здійснені спроби визначити сутнісні характеристики поняття «мова театру». Спираючись на різні підходи (семіотичні, культурологічні, театрознавчі), своє трактування родової ознаки театрального мистецтва запропонували П. Паві [32], Ю. Лотман [33], О. Клековкін [34] та ін. Однак наукового консенсусу не було досягнуто.

Здійсненій аналіз дає змогу стверджувати, що впродовж багатьох десятиліть відбувався інтенсивний пошук відповідей на питання про сутність і специфіку образної мови театру. Складність цього завдання, зумовлена самою природою досліджуваного явища, не зупиняла, проте, ані митців, які намагалися дати теоретичне обгрунтування власних творчих пошуків, ані науковців, які прагнули осягнути динамічну й мінливу лексику театру в його постійних перетвореннях.

\section{Джерела та література}

1. Мейерхольд В. Э. Из выступления на дискуссии «Творческая методология театра имени Мейерхольда» (25 декабря 1930 г.) / В. Э. Мейерхольд. Статьи, письма, речи, беседы : в 2 ч. - М. : Искусство, 1968. - Ч. 2 : 1917-1939. - 523 с. 
2. Клековкін O. Doctor Dappertutto: Театр фантазій Всеволода Мейєрхольда / О. Клековкін. - ІПСМ НАМ України. - К. : Арт Економі, 2014. - 208 с.

3. Грипич А. Учитель сцены // Встречи с Мейерхольдом : Сб. воспоминаний. - М. : ВТО, 1967. - 662 с.

4. Гладков А. Пять лет с Мейерхольдом. Встречи с Пастернаком / А. Гладков. Мейерхольд В. Э. Статьи, письма, речи, беседы : в 2 ч. - М. : СТД РСФСР, 1990. - Т. 2. $473 \mathrm{c}$.

5. Гвоздев А. Театр имени Вс. Мейерхольда (1920-1926) ; чертежи Э. Каплана /А. Гвоздев. - Л. : Academia, 1927 // Современный театр. - Вып.1. - 55 с.

6. Лесь Курбас у театральній діяльності, в оцінках сучасників: документи. - Балтимор ; Торонто : Українське Видавництво «Смолоскип» ім. В. Симоненка, 1989. - 1026 с.

7. Курбас Лесь. Березіль: із творчої спадщини / Лесь Курбас. - К. : Дніпро, 1988. - 517 с.

8. Василько В. Фрагменти режисури / В. Василько. - К. : Мистецтво, 1967. - 382 с.

9. Михайло Верхацький. 100: дні і праця, листування, спогади сучасників: до 100-річчя 3 дня народження ; упоряд. Лабінський М. - К. : Проза, 2004. - 240 с.

10. Бондарчук С. К. Молодий театр [c.103-166] / Молодий театр: Генеза. Завдання. Шляхи / упоряд. Лабінський М. К. : Мистецтво, 1991. - 316 с.

11. Довбищенко В. С. Театр / В. Довбищенко. - К. : Мистецтво, 1984.

12. Попов А. Д. Творческое наследие / А. Д. Попов. - М.: ВТО, 1979. - $517 \mathrm{c}$.

13. Товстоногов Г. А. Зеркало сцены: в 2-х кн. / Г. Товстоногов. - Л. : Искусство, 1980. - Кн. 2. -311 с.

14. Варпаховский Л. В. Наблюдения. Анализ. Опыт / Л. В. Варпаховский. - М. : ВТО, 1978. -275 с.

15. Лідер Д. Образ вистави // Український театр. - 1972. № 4. - С. 7-8.

16. Лідер Д. Театр для себе / О. Ковальчук // Студії мистецтвознавчі. - К. : ІМФЕ НАН України, 2007. - № 3(19). C. 141-142.

17. Френкель М. А. Современная сценография / М. А. Френкель. - К. : Мистецтво, 1980. - 132 с.

18. Френкель М. Пластика сценического пространства (Некоторые вопросы теории и практики сценографии) / М. Френкель. - К. : Мистецтво, 1987. - 183 с.

19. Барба Е. Паперове каное / Е. Барба. - Л. : Літопис, 2001. $288 \mathrm{c}$.

20. Брук П. Пустое пространство. Секретов нет / Питер Брук. - М : Артист. Режиссер. Театр, 2003. - 367 с.

21. Гротовский Е. К Бедному театру / Е. Гротовский. - М. : Артист. Режиссер. Театр, 2009. - 298 с.

22. Гвоздєв О. 3 історії театру і драми / О. Гвоздєв. - Львів : ВЦ ЛНУ ім. І. Франка, 2008. - 200 с.

23. Алперс Б. В. Театральные монографии / Б. В. Алперс. Театральные очерки : в 2-х т. - Т. 1. - М. : Искусство, 1977. $-567 \mathrm{c}$.

24. Марков П. А. Из истории русского и советского театра / П. А. Марков. О театре : в 4-х т. - М. : Искусство, 1974. T. 1. $-542 \mathrm{c}$.

25. Бальме К. Вступ до театрознавства / К. Бальме. - Львів : Вид. центр ЛНУ ім. Івана Франка, 2008. - 199 с.

26. Леман X.-T. Постдраматический театр / X.-T. Леман. M. : ABCdesign, 2013. $-312 \mathrm{c}$.

27. Михайлова А. А. Образ спектакля / А. А. Михайлова. М. : Искусство, 1978. - 247 с.

28. Гей Н. К. Искусство слова / Н. К. Гей. - М. : Наука, 1967. $364 \mathrm{c}$.

29. Товстоногов Г. А. Зеркало сцены : в 2-х кн. / Г. Товстоногов. - Л. : Искусство, 1980. - Кн. 1. - 304 с.

30. Рехельс М. Режиссер - автор спектакля. Этюды о режиссуре / М. Рехельс. - Л. : Искусство, 1969. - 231 с.
31. Корниенко Н. Театральная эстетика Леся Курбаса / Лесь Курбас: Статьи и воспоминания о Лесе Курбасе. - М. : Искусство, 1987. -463 с.

32. Паві П. Словник театру / П. Паві. - Львів : ВЦ ЛНУ ім. Івана Франка, 2006. - 639 с.

33. Лотман Ю. Язык театра // Театр. - 1989. - №3. - С. 101-104.

34. Клековкін О. Theatrica: Лексикон / Олександр Клековкін. - ІПСМ НАМ України. - К. : Фенікс, 2012. - 800 с.

\section{References}

1. Meyerhold, V. E. (1968). From the presentation to the discussion 'The creative methodology of the Meyerhold theater' (December 25, 1930) / Meyerhold V. E. Articles, letters, speeches, conversations: in 2 parts. - Moscow : Iskusstvo. - Ch. 2 : 1917-1939, 523 [in Russian].

2. Klekovkin, O. (2014). Doctor Dappertutto: Theatre of fantas ies of Vsevolod Meyerhold. - IPSM NAM Ukrainy. - Kyiv : Art Ekonomi, 208 [in Ukrainian].

3. Gripich, A. (1967). Teacher of the stage // of Meeting with M eyerhold : Sb. remembrances. - Moscow : VTO, 662 [in Russian].

4. Gladkov, A. (1990). Five years with Meyerhold. Meetings with Pasternak / Meyerhold V. E. Articles, letters, speeches, conversations: in 2 parts. - Moscow : STD RSFSR. - T. 2, 473 [in Russian].

5. Gvozdev, A. (1927). Vs. Meyerhold Theatre 1920-1926); drafts of E. Caplan. - L. : Academia // The modern theatre. Vyp.1, 55 [in Russian].

6. Les Kurbas in theater activities, in the estimations of contemporaries: documents (1989). - Baltymor ; Toronto : Ukrainske Vydavnytstvo «Smoloskyp» im. V. Symonenka, 1026 [in Ukrainian].

7. Kurbas, Les. (1988). Berezil: from the creative heritage. Kyiv : Dnipro. - 517 [in Ukrainian].

8. Vasylko V. (1967). Fragments of directing. - Kyiv : Mystetstvo, 382 [in Ukrainian].

9. Mikhail Verhatsky. 100: days and labor, correspondence, memories of contemporaries: to the 100th anniversary of birth ; uporiad. Labinskyi M. (2004). - Kyiv : Proza, 240 [in Ukrainian].

10. Bondarchuk, S. K. (1991). The Young Theater [p.103-166]/ The Young Theater: Genesis. Task. Ways ; uporiad. Labinskyi M. - Kyiv : Mystetstvo, 1991, 316 [in Ukrainian].

11. Dovbyshchenko, V. S. (1984). Theatre. - Kyiv : Mystetstvo, 204 [in Ukrainian].

12. Popov, A. D. (1979). Creative heritage: memories and reflections on the theatre. - Moscow : VTO, 517 [in Russian].

13. Tovstonogov, G. A. (1980). Mirror of the stage: in 2 books. Leningrad : Iskusstvo. - Kn. 2, 311 [in Russian].

14. Varpahovskiy, L. V. (1978). Observations. Analysis. Experience. - Moscow : VTO, 275 [in Russian].

15. Lider, D. (1972). The image of the performance // Ukrainian Theater. - № 4. - S. 7-8 [in Ukrainian].

16. Lider, D. (2007) .Theater for myself // Art studies studios. Kyiv : IMFE NAN Ukrainy. - № 3(19). - S. 141-142 [in Ukrainian].

17. Frenkel, M. A. Modern scenography (1980). - Kyiv : Mystetstvo. - 132 s. [in Russian].

18. Frenkel, M. Plastics of the stage space (Some questions in the theory and practice of scenography) (1987). - Kyiv : Mistetstvo, 183 [in Russian].

19. Barba, E. Paper Canoe (2001). - Lviv : Litopis. - 288 [in Ukrainian].

20. Bruk, P. An empty space. There are no secrets (2003). Moscow: Artist. Rezhisser. Teatr, 367 [in Russian].

21. Grotovskiy, E. To The Poor Theater (2009). - Moscow : Artist. Rezhisser. Teatr, 298 [in Russian]. 
22. Gvozdev, O. About the history of the theater and drama (2008). - Lviv : VTs LNU im. I. Franka, 200 [in Russian].

23. Alpers, B. V. Theatrical monographs (1977). Alpers B. V. Theatrical contrasts: in 2 volumes. - T. 1. - Moscow : Iskusstvo, 567 [in Russian].

24. Markov, P. A. From the history of Russian and Soviet theater (1974) / Markov P. A. About the theater: in the 4th century. Moscow : Iskusstvo. - T. 1., 542 [in Russian].

25. Balme, K. Introduction to Theater Studies (2008). - Lviv : VTs LNU im. Ivana Franka, 199 [in Ukrainian].

26. Lemann, H.-T. Post-drama Theater (2013). - Moscow : ABCdesign, 312 [in Russian].

27. Mihaylova, A. A. The image of the play (1978). - Moscow : Iskusstvo, 247 [in Russian].
28. Gey, N. K. The Art of the Word (1967). - Moscow : Nauka, 364 [in Russian].

29. Tovstonogov, G. A. Mirror of the scene: in 2 books. (1980). Leningrad : Iskusstvo. - Kn. 1., 304 [in Russian].

30. Rehels, M. The director is an author of the spectacle. Etudes about directing (1969). - Leningrad : Iskusstvo, 231. [in Russian].

31. Kornienko, N. Theatrical aesthetics of Les Kurbas / Les Kurbas: Articles and memoirs about Les Kurbas (1987). Moscow : Iskusstvo, 463 [in Ukrainian].

32. Pavi, P. The Dictionary of the Theater (2006). - Lviv : VTs LNU im. Ivana Franka, 639 [in Ukrainian].

33. Lotman, Yu. The Language of the Theater (1989) // Teatr. №3. - S. 101-104. [in Russian].

34. Klekovkin, O. Theatrica: Lexikon (2912). - IPSM NAM Ukrainy. - Kyiv : FENIKS, 800 [in Ukrainian]. 